\title{
APPLICATION OF LIDAR TO FOREST INVENTORY FOR TREE COUNT IN STANDS OF Eucalyptus sp
}

\author{
Luciano Teixeira de Oliveira1 ${ }^{1}$, Luis Marcelo Tavares de Carvalho², Maria Zélia Ferreira ${ }^{3}$, \\ Thomaz Chaves de Andrade Oliveira ${ }^{4}$, Fausto Weimar Acerbi Junior ${ }^{5}$
}

(received: May 18, 2011; accepted: December 22, 2011)

\begin{abstract}
Light Detection and Ranging, or LIDAR, has become an effective ancillary tool to extract forest inventory data and for use in other forest studies. This work was aimed at establishing an effective methodology for using LIDAR for tree count in a stand of Eucalyptus sp. located in southern Bahia state. Information provided includes in-flight gross data processing to final tree count. Intermediate processing steps are of critical importance to the quality of results and include the following stages: organizing point clouds, creating a canopy surface model (CSM) through TIN and IDW interpolation and final automated tree count with a local maximum algorithm with $5 \times 5$ and $3 \times 3$ windows. Results were checked against manual tree count using Quickbird images, for verification of accuracy. Tree count using IDW interpolation with a $5 \times 5$ window for the count algorithm was found to be accurate to $97.36 \%$. This result demonstrates the effectiveness of the methodology and its use potential for future applications.
\end{abstract}

Key words: Airborne laser scanning, tree detection, Local Maximum.

\section{APLICAÇÃO DO LIDAR NO INVENTÁRIO DE FLORESTAS PLANTADAS COM Eucalyptus sp PARA CONTAGEM DE ÁRVORES}

RESUMO: O Light Detection and Ranging, ou LIDAR, tem se tornado uma eficiente ferramenta auxiliar para a extração de dados no inventário florestal e também em outros estudos florestais. Este trabalho foi realizado com o objetivo de estabelecer uma metodologia eficiente para a utilização do LIDAR para a contagem do número de árvores em um povoamento de Eucalyptus sp., localizado no sul do Estado da Bahia. Apresenta-se desde o processamento dos dados brutos obtidos em voo até o número final da contagem de árvores. Os passos intermediários são de vital importância para a qualidade dos resultados e os mesmos são obtidos por meio das seguintes etapas de processamento: organização da nuvem de pontos; criação do modelo de superfície do dossel (MSD) por meio da geração de uma TIN e interpolação Inverse Distance Weighted (IDW) e contagem automatizada final das árvores com um algoritmo de máxima local com janelas de $5 \times 5$ e $3 \times 3$. Os resultados obtidos foram comparados à contagem manual das árvores em imagens Quickbird para a verificação da acurácia. O acerto da contagem foi de 97,36\% por meio da interpolação IDW com a janela de $5 X 5$ para o algoritmo de contagem. Esse resultado evidencia a eficácia da metodologia produzida e o potencial para futuras aplicações.

Palavras-chave: Laser aerotransportado, detecção de árvores, Local Máxima.

\section{INTRODUCTION}

With the expansion of the forestry sector and with timber increasingly becoming a scarce commodity, it becomes vital that long-, medium- and short-term planning be more and more accurate to ensure timber availability over time, maximizing timber yield and reducing production costs.

Bearing this in mind, forest planners are more and more in search of tools from which to derive accurate information on current forest stock, also looking to model future forest yield. Conventional continuous or prefelling inventory procedures have always been used by forest companies to attain that, constituting a strategic planning tool in that they allow estimation of the dendrometric variables required to determine present and future timber stock with desirable accuracy and viable cost (SCOLFORO; MELLO, 2006).

In Brazil, continuous forest inventory is one of the most popular ways of monitoring forest growth. In

\footnotetext{
${ }^{1}$ Forest Engineer, D.Sc. in Forest Engineering - Departamento de Ciências Florestais/DCF - Universidade Federal de Lavras/UFLA - Cx. P. 3037 37200-000 - Lavras, MG, Brasil - oliveiralt@hotmail.com

${ }^{2}$ Forest Engineer, Professor Ph.D. in Geosciences and the Environment - Departamento de Ciências Florestais/DCF - Universidade Federal de Lavras/UFLA - Cx. P. 3037 - 37200-000 - Lavras, MG, Brasil - passarinho@dcf.ufla.br

${ }^{3}$ Forest Engineer, D.Sc. in Forest Sciences - Veracel Celulose S.A - Cx. P. 23 - 45820-970 - Eunápolis, BA, Brasil - maria.zelia@veracel.com.br ${ }^{4}$ Bachelor of Computer Sciences, D.Sc. candidate in Electrical Engineering - Faculdade de Engenharia Elétrica e de Computação - Universidade Estadual de Campinas/UNICAMP - Av. James Clerck Maxwell, Cidade Universitária "Zeferino Vaz" - 3013083-868 - Campinas, SP, Brasil thomazchaves@gmail.com

${ }^{5}$ Forest Engineer, Ph.D. candidate in Geosciences and the Environment - Departamento de Ciências Florestais/DCF - Universidade Federal de Lavras/UFLA - Cx. P. 3037 - 37200-000 - Lavras, MG, Brasil - fausto@dcf.ufla.br
}

Cerne, Lavras, v. 18, n. 2, p. 175-184, abr./jun. 2012 
this type of inventory, permanent plots are installed when stands reach age two or three years, being systematically remeasured at intervals of one to two years (KANEGAE JUNIOR et al., 2006; OLIVEIRA, 2006). It has been observed, however, that some inconsistencies may be associated with conventional inventories, including bias in diameter and height mensurations, error in data handling, error in plot area measurements and, especially, errors associated with the sampling procedure, which may vary depending on the dendrometric variable being analyzed, being particularly high for the variable 'number of trees per hectare'. Errors of this sort lead to impaired data quality and thus generate imprecise growth and yield models, consequently affecting forest planning at large. Sampling errors can only be resolved if a census is conducted in the relevant area.

Remote sensing has been proving an important tool for the development of forest sciences, potentially allowing significant gains in forest inventory by helping improve estimates and/or reduce sampling intensity (SOUZA et al., 2007).

Use of Light Detection and Ranging, or LIDAR, for accurate determination of land elevation began in the second half of the 1970s (LILLESAND; KIEFER, 2000 ) and, since the 1980s, its use for forest applications has progressed considerably. As high resolution spatial imagery becomes increasingly available, it also becomes possible to obtain forest information on individual trees rather than on plots or stands as a whole (DISPERATI et al., 2007). When a laser beam propagates in space, it has a divergence that results in the diameter of the point cast on the surface (footprint). This area coverage corresponds to the spatial resolution of LIDAR imagery (JENSEN, 2009; LEE; LUCAS, 2007).

Several studies have been conducted for use of LIDAR in inventories of planted forests, whether to estimate plot or individual tree parameters. They include the works of Castro and Centeno (2005), Crow et al. (2007), Heurich and Thoma (2008), Ioki et al. (2010), Jupp et al. (2007), Lauri et al. (2008), Macedo (2009), Maltamo et al. (2004), Naesset and Bjerknes (2001), Popescu (2002), Sasaki et al. (2008), Tiede et al. (2005), Yu et al. (2004), Zandoná et al. (2008), Zonete (2009) and Zonete et al. (2010).

Considering the above, this work was generally aimed at developing methodologies to improve use of distance measurement data by using light waves, or LIDAR, in forest inventory.

Cerne, Lavras, v. 18, n. 2, p. 175-184, abr./jun. 2012
Specific objectives included:

- generate a tree count methodology for stands of Eucalyptus sp. with spacing of $4 \times 3 \mathrm{~m}$, at age 3 years;

- test two local maximum filters, $5 \times 5$ and $3 \times 3$, in stands of Eucalyptus sp. with spacing of $4 \times 3 \mathrm{~m}$, at age 3 years;

- test two interpolators, inverse distance weighted interpolation (IDW) and triangulated irregular network (TIN), in order to characterize the situation of the tree canopy for Eucalyptus sp.;

- test the two interpolators, at different heights, in the two stands of Eucalyptus sp. at age 3 years.

\section{MATERIAL AND METHODS}

\subsection{Study site}

The study site lies in the southernmost portion of Bahia state, between coordinates $16^{\circ} 7^{\prime} 21^{\prime \prime} \mathrm{S} ; 39^{\circ} 21^{\prime} 48^{\prime \prime} \mathrm{W}$ and $16^{\circ} 7^{\prime} 36^{\prime \prime} \mathrm{S} ; 39^{\circ} 21^{\prime} 22^{\prime \prime} \mathrm{W}$ (Figure 1). Being a coastal region, the local rates of rainfall are high and well distributed throughout the year, and the local topography is flat.

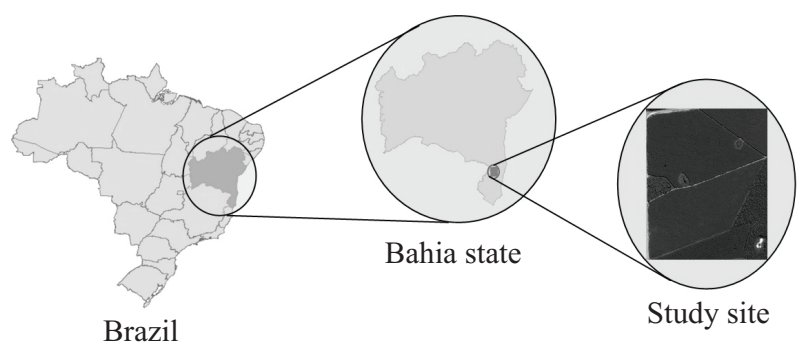

Figure 1 - Geographic location of the LIDAR-scanned stands.

Figura 1 - Localização geográfica dos talhões escaneados com o LIDAR.

Two eucalyptus stands at age three years were used in this study, cultivated with different clones. At three years, stands are young and tree crowns do not intertwine, and it is also at this age that continuous inventory usually begins, hence it being selected. Stand 1 (clone ' $a$ ') has an area of 21.71 ha with spacing of $3 \times 4 \mathrm{~m}$ and has 17,495 tree stems (information obtained by visual tree count using a Quickbird image from /09/April/2007). Stand 2 (clone 'b') has an area of 21.76 ha with spacing of $3 \times 4 \mathrm{~m}$ and has 17,390 tree stems (information also obtained by visual count). These stands were inventoried using circular plots of $531 \mathrm{~m}^{2}$, with the center being georeferenced with DGPS and with 4 plots being randomly distributed per stand. 
Table 1 provides the area obtained for the stands against the area reported in existing records, and summarizes information on tree stems in the stands through inventory estimation and visual tree count. In this study, inventory estimation data are only illustrative, since the approach to the technique is intended to determine the exact number of trees in the stand, in addition to the fact that the inventory had a higher sampling intensity than the traditional company's inventory.

Table 1 - Determination of all existing trees in two stands and difference in area.

Tabela 1 - Determinação de todas as árvores existentes nos povoamentos nos dois talhões e diferença de áreas.

\begin{tabular}{lcccc}
\hline & $\begin{array}{c}\text { Visual } \\
\text { count }\end{array}$ & $\begin{array}{c}\text { Inventory } \\
\text { estimate }\end{array}$ & $\begin{array}{c}\text { Area reported } \\
\text { in company } \\
\text { records }\end{array}$ & $\begin{array}{c}\text { Area } \\
\text { obtained by } \\
\text { LIDAR }\end{array}$ \\
\hline Stand 1 & 17,495 & $17,486.33$ & 21.71 ha & 22.05 ha \\
Stand 2 & 17,390 & $18,135.72$ & 21.76 ha & 21.75 ha \\
\hline
\end{tabular}

\subsection{LIDAR data acquisition and preprocessing}

LIDAR data were collected between 5 and 9 September 2008, using an ALTM 3100 system coupled to a twin-engine Piper Seneca II aircraft. The flight was operated at $150 \mathrm{~km} / \mathrm{h}$, at an altitude of $1,000 \mathrm{~m}$, with a beam diameter of $20 \mathrm{~cm}$, a beam divergence of $0.3 \mathrm{mrad}$, a scanning angle of $15^{\circ}$, a scanning frequency of $58.7 \mathrm{~Hz}$ and 1.5 point intensity per square meter. The planimetric error was $0.5 \mathrm{~m}$ (1.0 sigma), the altimetric error was 0.15 $\mathrm{m}$ (1.0 sigma) and the laser area coverage was $0.32 \mathrm{~m}$.

When a laser signal reaches objects without a well-defined surface, it may produce various reflection records (returns or pulses). Although some LSA systems, such as Aeroscan (Leica), are capable of registering the return of up to 5 pulses, in forestry studies the most important pulses are the first and the last: the first provides information on the uppermost portion of objects and is used for canopy surface modeling; the last pulse is reflected on the lowest level reached by the laser and is used for terrain modeling. This allows separating low ground vegetation for generation of a digital heights model (CASTRO; CENTENO, 2005; COELHO; VARGAS, 2007; JENSEN, 2009; MIQUELES et al., 2003).

Data from LIDAR signals related to the area of the two stands were structured based on information about coordinates latitude, longitude, altitude (x, y, z), returns (1st, 2nd and 3rd pulse) and signal intensity. The result of this systemization is a spreadsheet where each laser pulse is depicted in rows and its respective information is provided in columns. This information determines the point density of the resulting cloud. Density can range between 0.5 and 5 points per square meter, where the accuracy of the laser scanner is in the order of about $15 \mathrm{~cm}$ (CROW et al., 2007). Each row in the spreadsheet can also be depicted using $\mathrm{x}, \mathrm{y}$ and $\mathrm{z}$ coordinates, forming a point cloud in three-dimensional space which is stored in vector file format in the Geographic Information System.

Once information was structured, the flight route of the aircraft was analyzed so as to avoid overlay of successive passages. Overlay information was ignored in this study because of the greater concentration of noise observed in such areas. This was probably due to canopy shift influenced by wind at different aircraft passages.

\subsection{LIDAR data processing}

In order to better understand the methodology, Figure 2 provides a step sequence diagram for its implementation.

At this stage, point cloud information was separated into terrain models (DTM) and surface models (DSM). For that, binary logic rules were used assessing information on pulse, altitude, vertical and horizontal angulation between adjacent points with the standard deviation of the altitudes of each pulse. The point cloud can be assessed three-dimensionally, as rendered in Figure 3.

With the difference of DTM and DSM, height information was generated for all points relative to the soil. Concurrently, the point cloud was categorized as follows:

- Soil (points with one return only and last returns of the remaining points, which interact with a flat angulation of $8^{\circ}$ and a vertical angulation of $88^{\circ}$ through a triangulation with neighboring points, up to 8 standard deviations);

- Undergrowth (points $0.35 \mathrm{~m}$ to $2.5 \mathrm{~m}$ in height relative to the soil);

- Branches (points $2.5 \mathrm{~m}$ to $13 \mathrm{~m}$ in height relative to the soil);

- Canopy above $13 \mathrm{~m}$ (canopy with branches above $13 \mathrm{~m}$ in height);

- Canopy above 14 m (canopy with branches above $14 \mathrm{~m}$ in height).

Cerne, Lavras, v. 18, n. 2, p. 175-184, abr./jun. 2012 

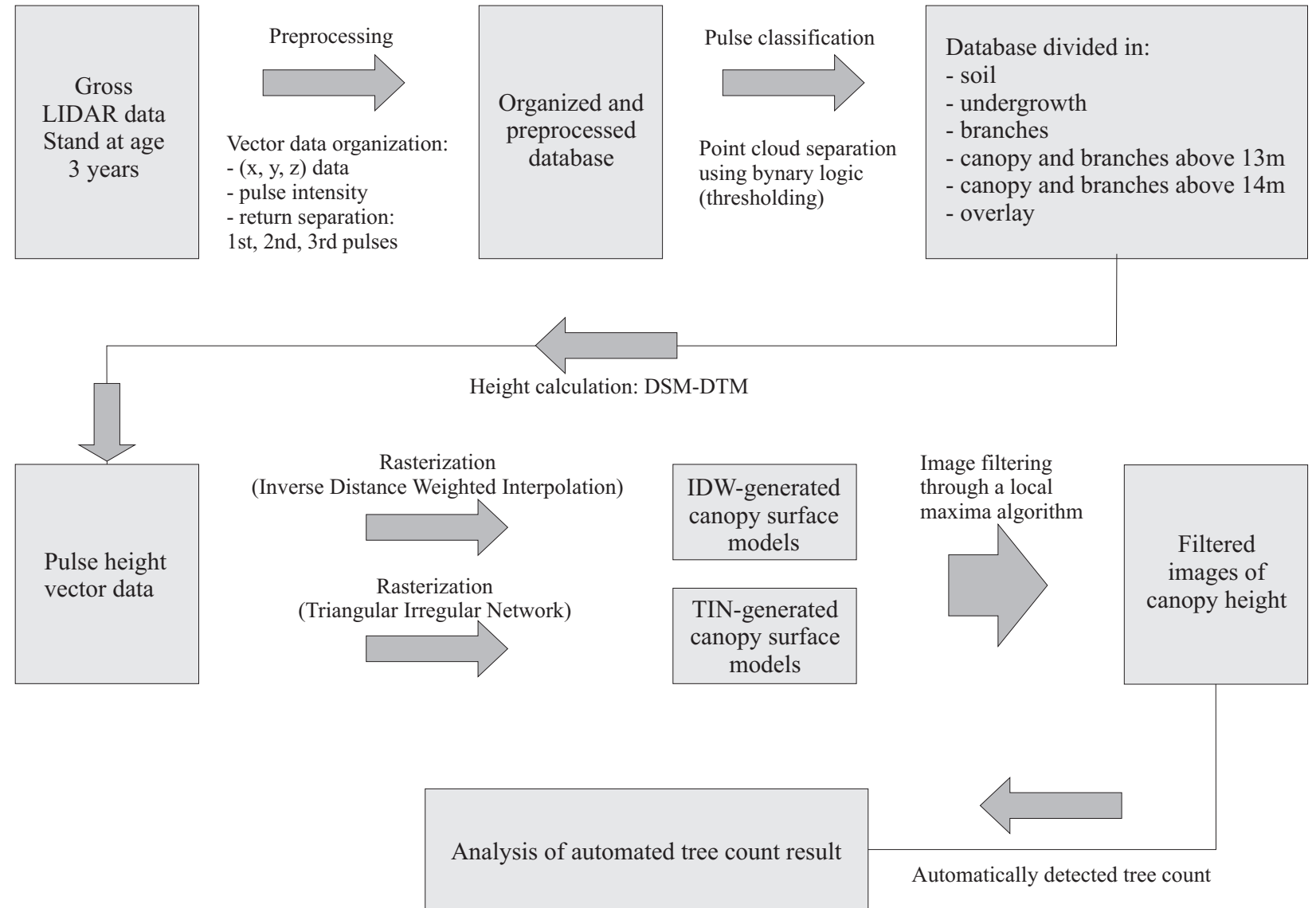

Figure 2 - Tree count step methodology diagram.

Figura 2 - Esquema de passos para a execução da metodologia de contagem de árvores.

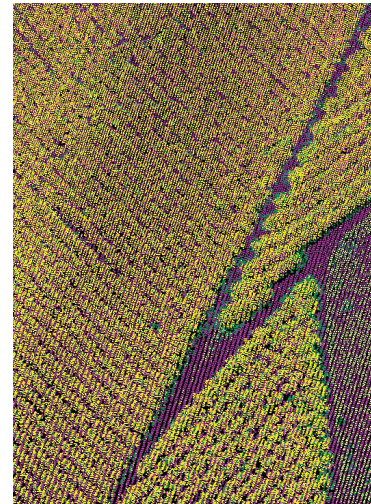

(a)

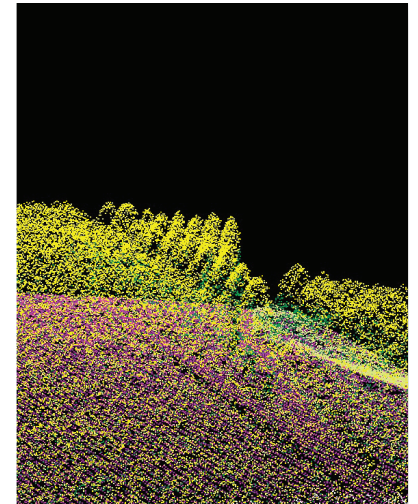

(b)

Figure 3 - Rendered LIDAR 3D point cloud, originated in the stand of Eucalyptus sp.

Figura 3 - Nuvem de pontos $3 D$ do LIDAR renderizadas, originadas do povoamento de Eucalyptus sp.

Cerne, Lavras, v. 18, n. 2, p. 175-184, abr./jun. 2012

Canopy above 13 meters and canopy above 14 meters were selected because it was at these average heights that tree crowns started in each stand. This division was necessary because the clones differed by about $1 \mathrm{~m}$ as to where the crown base started, and by about $2 \mathrm{~m}$ in the total height (Figure 4).

Height information was used for all classes as a whole and separately for application of IDW (Figures 5a to 5e) and TIN (Figures $5 \mathrm{f}$ to $5 \mathrm{j}$ ) interpolations (BURROGH; MCDONNELL, 1998). In this data set, a variation was observed in the shade gradation of the images. This variation influences height values, crown shape and points of local maxima, causing some trees to be excluded or divided in the detection result. Figure 5 indicates detected trees through red dots and undetected trees through red circles. The resulting effect of TIN triangulation is depicted in Figure 5j (red square). 


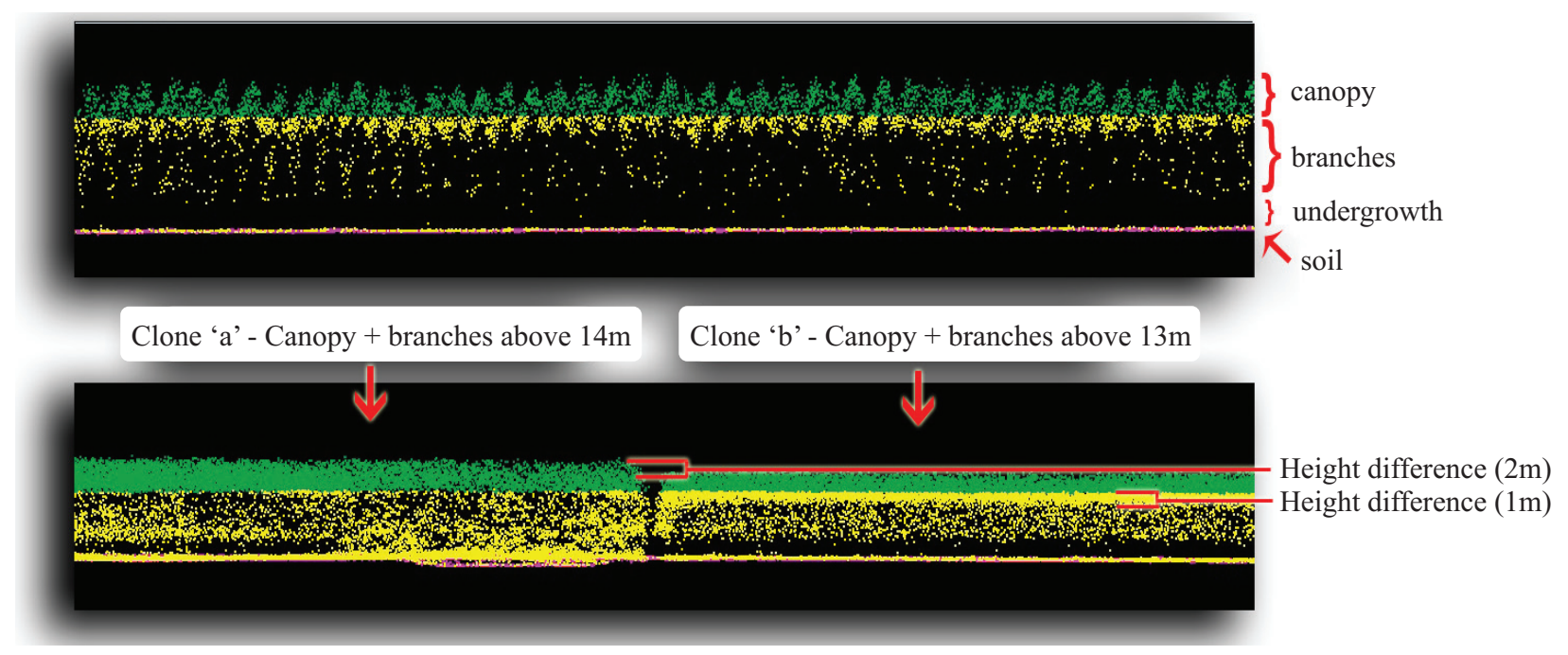

Figure 4 - Profile of the Eucalyptus sp. stand as depicted by LIDAR point cloud.

Figura 4-Perfil do povoamento de Eucalyptus sp. na nuvem de pontos obtidas pelo LIDAR.

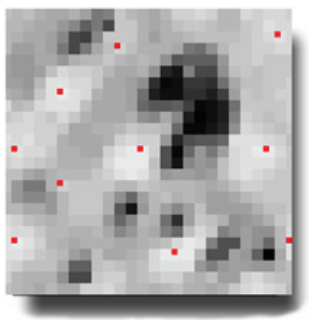

(a)

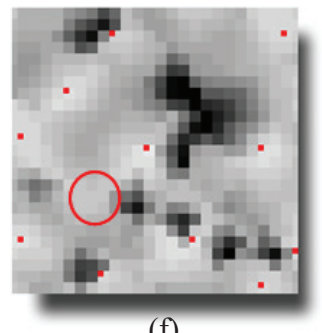

(f)

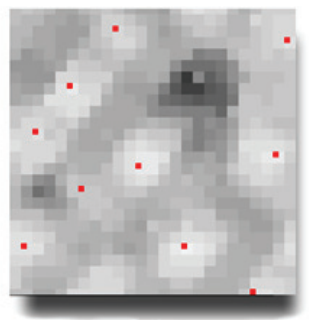

(b)

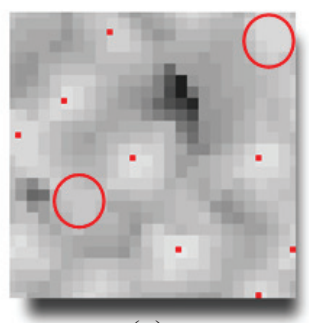

(g)

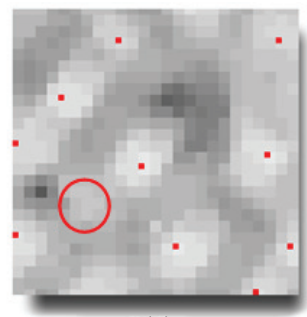

(c)

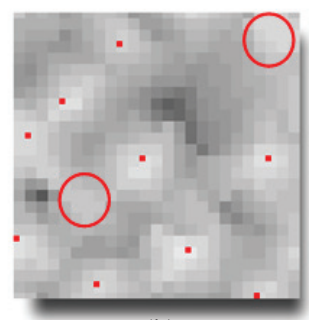

(h)

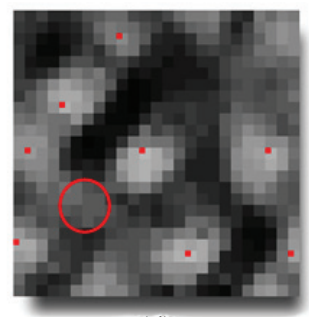

(d)

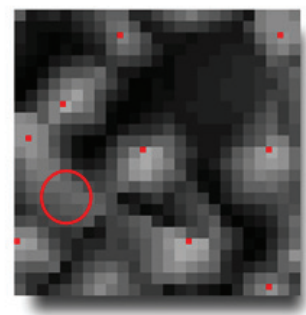

(i)

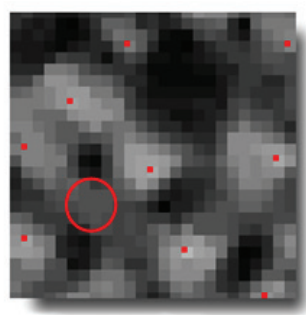

(e)

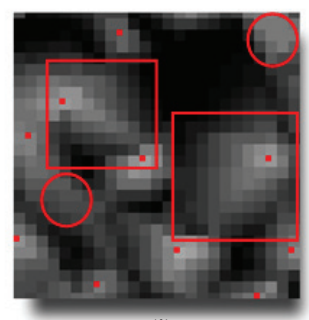

(j)

Figure 5 - Results of IDW interpolation: (a) including all first returns from soil to canopy, (b) returns from undergrowth to canopy (c) branches to canopy (d) canopy and branches above $13 \mathrm{~m}$ (e) canopy and branches above $14 \mathrm{~m}$; TIN interpolation is exemplified in figures (f) through (j) with the same return sequence situations.

Figura 5 - Resultados dos interpoladores IDW: (a) incluindo todos os primeiros retornos desde o solo até o dossel, (b) retornos desde a vegetação rasteira até o dossel (c) galhos até o dossel (d) dossel e galhos acima de $13 \mathrm{~m}$, (e) dossel com galhos acima de 14 m; o interpolador TIN é utilizado nas figuras de (f) a (j) com a mesma sequência de situações para os retornos.

After converting information into raster format, a local maximum filter was applied (CARVALHO, 2001, 2008), with $3 \times 3$ and $5 \times 5$ moving windows, in order to compute all existing trees in the stand. This result was compared to plot inventory estimates (Table 1) and these two methods were checked against information obtained by visual count using a Quickbird image from 09/April/2007 (Figure 6).

Cerne, Lavras, v. 18, n. 2, p. 175-184, abr./jun. 2012 

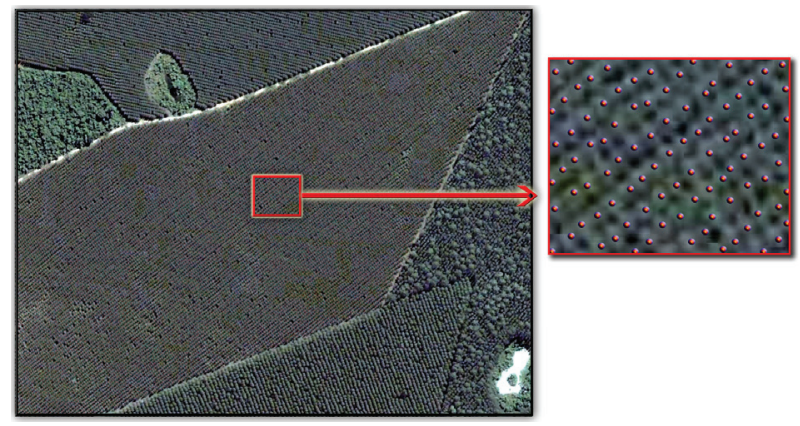

Figure 6 - Manual tree count using Quickbird images.

Figura 6 - Contagem manual das árvores, utilizando imagens Quickibird.

\section{RESULTS AND DISCUSSION}

Data obtained with the local maximum algorithm using $3 \times 3$ filtering (Tables 2 and 3 ) were not as effective if compared with results obtained using $5 \times 5$ filtering (Tables 4 and 5), since all results found with $3 \times 3$ filtering tended to overestimate the number of individuals in the stand, generating a higher error of commission. This result contrasted with the result obtained with $5 \times 5$ filtering, which tended to underestimate the population in both stands and detected values closer to reality, with a minor error of omission. This result relates to the spacing being used in the plantation ( $4 \times 3$ ), suggesting that if spacing is reduced in the study site, the $3 \times 3$ filter may have better performance while the $5 \times 5$ filter, worse.

These results can be rated excellent, considering that Zadoná et al. (2008) found an average accuracy of $82.8 \%$, against the $98.85 \%$ reached with the proposed methodology in stand 1, equivalent to an error of 202 trees in a population of 17,293 trees (Table 4), and $96.58 \%$ in stand 2 which is equivalent to 599 trees in a population of 16,791 trees (Table 5). Results are also very satisfactory in relation to Norway Spruce and Scots Pine forests in the work of Maltamo et al. (2004), who obtained an accuracy of $91.8 \%$ for the average number of trees per plot using a similar methodology to generate a canopy surface model. The result found by McCombs et al. (2003) for two stands with spacing of $2.4 \mathrm{~m}$ and $3.0 \mathrm{~m}$ was $64.7 \%$ and $87.3 \%$, yet by merging statistics with multispectral $(550,675,700$ and $800 \mathrm{~nm})$ and high resolution data $(0.61 \mathrm{~m})$ they improved the result to $83.5 \%$ and $94.8 \%$, outlining a potential methodology for improvement of tree count results. Morsdof et al. (2004) found that only $60.48 \%$ of the existing trees were

Table 2 - Tree detection by the local maximum algorithm using 3 x 3 filtering, for stand 1 .

Tabela 2 - Detecção de árvores pelo algoritmo de máxima local, filtro $3 \times 3$, para o talhão 1 .

\begin{tabular}{lcccccc}
\hline Classes generated with 1st pulse & $\begin{array}{c}\text { (TIN) } \\
\text { trees }\end{array}$ & $\begin{array}{c}\text { Error } \\
(\text { no. trees })\end{array}$ & $\begin{array}{c}\text { Error } \\
(\%)\end{array}$ & $\begin{array}{c}\text { (IDW) } \\
\text { trees }\end{array}$ & $\begin{array}{c}\text { Error } \\
\left(\mathrm{n}^{\circ} \text { trees }\right)\end{array}$ & $\begin{array}{c}\text { Error } \\
(\%)\end{array}$ \\
\hline All classes with soil & 26208 & -8713 & -49.80 & 29628 & -12133 & -69.35 \\
Undergrowth, branches and canopy & 24082 & -6587 & -37.65 & 26516 & -9021 & -51.56 \\
Branches and canopy & 22962 & -5467 & -31.25 & 25242 & -7747 & -44.28 \\
Canopy and branches above 13m & 21394 & -3899 & -22.29 & 22490 & -4995 & -28.55 \\
Canopy and branches above 14m & 21418 & -3923 & -22.42 & 22399 & -4904 & -28.03 \\
\hline
\end{tabular}

Table 3 - Tree detection by the local maximum algorithm using 3 x 3 filtering, for stand 2 .

Tabela 3 - Detecção de árvores pelo algoritmo de máxima local, filtro $3 \times 3$, para o talhão 2.

\begin{tabular}{lcccccc}
\hline Classes generated with 1st pulse & $\begin{array}{c}\text { (TIN) } \\
\text { trees }\end{array}$ & $\begin{array}{c}\text { Error } \\
\text { (no. trees) }\end{array}$ & $\begin{array}{c}\text { Error } \\
(\%)\end{array}$ & (IDW) & $\begin{array}{c}\text { Error } \\
(\text { no. trees) }\end{array}$ & $\begin{array}{c}\text { Error } \\
(\%)\end{array}$ \\
\hline All classes with soil & 20235 & -2845 & -16.26 & 23369 & -5979 & -34.17 \\
Undergrowth, branches and canopy & 19687 & -2297 & -13.13 & 22362 & -4972 & -28.42 \\
Branches and canopy & 19603 & -2213 & -12.65 & 22183 & -4793 & -27.40 \\
Canopy and branches above 13 m & 19093 & -1703 & -9.73 & 20447 & -3057 & -17.47 \\
Canopy and branches above 14 m & 19276 & -1886 & -10.78 & 20301 & -2911 & -16.64 \\
\hline
\end{tabular}

Cerne, Lavras, v. 18, n. 2, p. 175-184, abr./jun. 2012 
Table 4 - Tree detection by the local maximum algorithm using 5 x 5 filtering, for stand 1 .

Tabela 4 - Detecção de árvores pelo algoritmo de máxima local, filtro $5 \times 5$ para o talhão 1 .

\begin{tabular}{lcccccc}
\hline Classes generated with 1st pulse & $\begin{array}{c}\text { (TIN) } \\
\text { trees }\end{array}$ & $\begin{array}{c}\text { Error } \\
\text { (no. trees) }\end{array}$ & $\begin{array}{c}\text { Error } \\
(\%)\end{array}$ & (IDW) & $\begin{array}{c}\text { Error } \\
(\text { no. trees) }\end{array}$ & $\begin{array}{c}\text { Error } \\
(\%)\end{array}$ \\
\hline All classes with soil & 17033 & 462 & 2.64 & 17683 & -188 & -1.07 \\
Undergrowth, branches and canopy & 16732 & 763 & 4.36 & 17293 & 202 & 1.15 \\
Branches and canopy & 16736 & 759 & 4.34 & 17216 & 279 & 1.59 \\
Canopy and branches above 13 m & 16569 & 926 & 5.29 & 16957 & 538 & 3.07 \\
Canopy and branches above 14 m & 16560 & 935 & 5.34 & 16945 & 550 & 3.14 \\
\hline
\end{tabular}

Table 5 - Tree detection by the local maximum algorithm using 5 x 5 filtering, for stand 2 .

Tabela 5 - Detecção de árvores pelo algoritmo de máxima local, filtro $5 \times 5$, para o talhão 2.

\begin{tabular}{lcccccc}
\hline Classes generated with 1st pulse & $\begin{array}{c}\text { (TIN) } \\
\text { trees }\end{array}$ & $\begin{array}{c}\text { Error } \\
\text { (no. trees) }\end{array}$ & $\begin{array}{c}\text { Error } \\
(\%)\end{array}$ & (IDW) & $\begin{array}{c}\text { Error } \\
\text { (no. trees) }\end{array}$ & $\begin{array}{c}\text { Error } \\
(\%)\end{array}$ \\
\hline All classes with soil & 16771 & 619 & 3.54 & 16776 & 614 & 3.51 \\
Undergrowth, branches and canopy & 16718 & 672 & 3.84 & 16780 & 610 & 3.49 \\
Branches and canopy & 16706 & 684 & 3.91 & 16791 & 599 & 3.42 \\
Canopy and branches above 13 m & 16574 & 816 & 4.66 & 16435 & 955 & 5.46 \\
Canopy and branches above 14 m & 16390 & 1000 & 5.71 & 16316 & 1074 & 6.14 \\
\hline
\end{tabular}

detected using a K-means segmentation algorithm. This is partly due to canopy outspreading (spacing between tree crowns is often less than $1 \mathrm{~m}$ ). Other results can be found in Koch et al. (2006), who used the computer vision framework HALCON with Watersheding techniques for segmenting and discriminating between different crowns and decision rules. Results reveal an accuracy of $87.3 \%$, in which the author differentiates results as correct or at least satisfactory.

Despite proving more effective with $3 \times 3$ filtering than IDW (Tables 2 and 3), TIN was not thought of as ideal, since all Errors were higher than with 5 x 5 filtering, demonstrating that the latter is more suitable for the tree spacing being studied. Therefore, when comparing again TIN and IDW interpolations (Tables 4 and 5), IDW was found to have better performance, with less error than TIN for both stands, except for canopy in stand 2 .

It was noted that TIN interpolation tends to misrepresent the shape of tree crowns, as they tend to be rendered triangular (Figures $5 \mathrm{j}, 7 \mathrm{i}$ and $7 \mathrm{j}$ inside the red square). IDW interpolation, in turn, tends to preserve the shape of tree crowns, as illustrated in Figure 6, as a result of the high resolution optical image.
Another point to note is that when only canopy information is evaluated, a greater error is generated than when information is evaluated of combined canopy with branches and undergrowth for the entire population (Figures $7 \mathrm{a}$ to $7 \mathrm{j}$ ). This difference was found to be due to trees having impaired height growth as a result of a soil or fertilization condition, causing them to be suppressed in relation to the rest of the population. This assertion is illustrated by Figures 5 a to $5 \mathrm{e}$, which show that trees below canopy height level were not detected in the dominant tree layer.

By removing the error obtained from analysis of the population in relation to 1 st pulse information excluding soil, it was found that it is possible to generate a percentage of suppressed trees in the stand, as illustrated in Table 6 and in situations found in Figures 5 and 7 . Another important observation was that besides the number of trees present in the stand, height information which is more difficult to obtain and often less precise in forest inventories is also generated for each tree detected.

The above information can be very useful for assessing stand quality and site quality and for improving volume modeling, since suppressed trees will have less volume than the rest of the population.

Cerne, Lavras, v. 18, n. 2, p. 175-184, abr./jun. 2012 


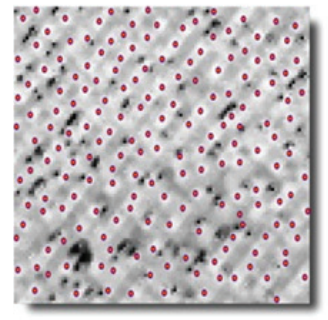

(a)

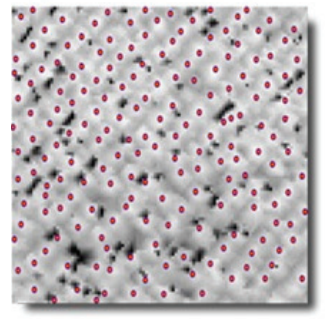

(f)

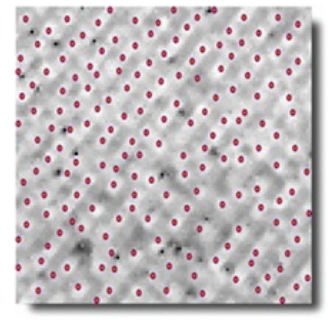

(b)

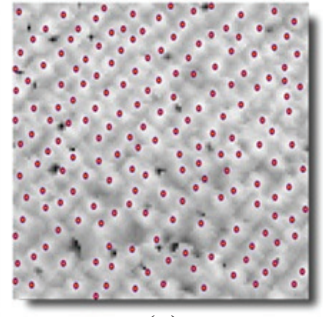

(g)

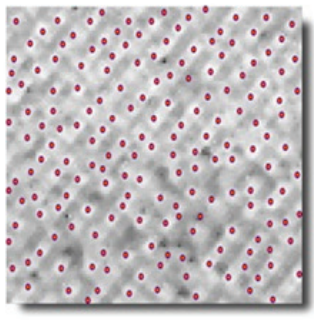

(c)

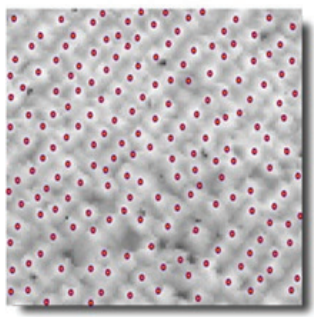

(h)

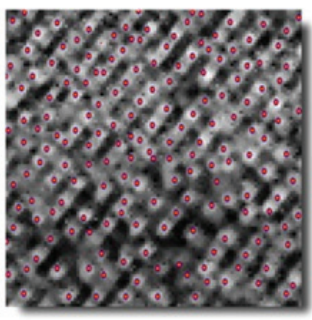

(d)

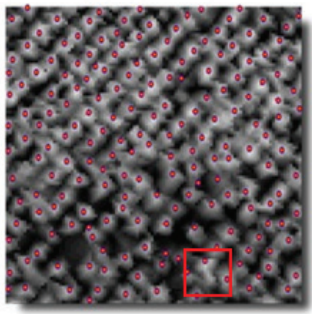

(i)

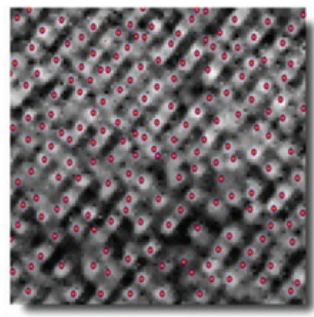

(e)

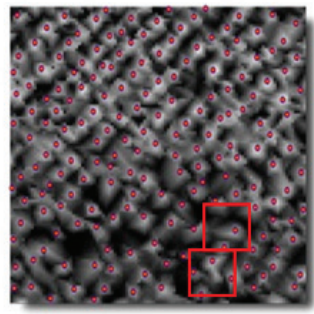

(j)

Figure 7 - Tree count results for data interpolated by IDW: (a) including all first returns from soil to canopy, (b) returns from undergrowth to canopy (c) branches to canopy (d) canopy and branches above $13 \mathrm{~m}$, (e) canopy and branches above $14 \mathrm{~m}$; data interpolated by TIN is exemplified in (f) through (j), with the same sequence situations.

Figura 7-Resultados da contagem para os dados interpolados por IDW: (a) incluindo todos os primeiros retornos desde o solo até o dossel, (b) retornos desde a vegetação rasteira até o dossel (c) galhos até o dossel (d) dossel e galhos acima de $13 \mathrm{~m}$, (e) dossel com galhos acima de $14 \mathrm{~m}$, e a mesma sequência para contagem usando os dados interpolados por TIN de (f) a (j).

Table 6 - Number of suppressed trees found in stands 1 and 2.

Tabela 6 - Número de árvores suprimidas encontradas nos talhões 1 e 2.

\begin{tabular}{lcccccc}
\hline Classes generated with 1st pulse & $\begin{array}{c}\text { No. trees } \\
\text { (Stand 2) }\end{array}$ & $\begin{array}{c}\text { Error } \\
\text { (no. trees) }\end{array}$ & $\begin{array}{c}\text { Error } \\
(\%)\end{array}$ & $\begin{array}{c}\text { No. trees } \\
\text { (Stand 1) }\end{array}$ & $\begin{array}{c}\text { Error } \\
(\text { no. trees) }\end{array}$ & $\begin{array}{c}\text { Error } \\
(\%)\end{array}$ \\
\hline All classes with soil & 16776 & - & - & 17683 & - & - \\
Undergrowth, branches and canopy & 16780 & 0 & 0 & 17293 & 0 & 0 \\
Branches and canopy & 16791 & - & - & 17216 & 77 & 0.44 \\
Canopy and branches above 13 m & 16435 & 345 & 1.97 & 16957 & 336 & 1.92 \\
Canopy and branches above 14 m & 16316 & 464 & 2.65 & 16945 & 348 & 1.99 \\
\hline
\end{tabular}

\section{CONCLUSIONS}

It was possible to generate a specific methodology to obtain forest inventory data, more specifically to do tree count in stands of Eucalyptus sp. with spacing of $4 \times 3 \mathrm{~m}$. For that, it was essential to use only information on branches and crown canopy, as obtained by using 1st pulse LIDAR data.

The 5 x 5 local maximum filter succeeded in detecting treetops, allowing tree count in stands aged 3 years, providing an error of 202 trees (1.15\%) in a population of 17,495 trees (clone 'a'), and 599 trees $(3.42 \%)$ in a population of 17,390 trees (clone ' $b$ ').

Cerne, Lavras, v. 18, n. 2, p. 175-184, abr./jun. 2012
Inverse distance weighted interpolation (IDW) proved more effective than the triangulated irregular network (TIN) procedure in characterizing tree canopy status for Eucalyptus sp.

With the proposed methodology, it was possible to indicate the number of suppressed trees in cloned stands of Eucalyptus sp. at age 3 years.

There are many challenges yet to be faced in order to use the full potential of information provided by LIDAR. Other studies should be conducted in order to evaluate this methodology for different stand ages, tree spacing and topographic conditions. 


\section{REFERENCES}

BURROGH, P. A.; MCDONNELL, R. A. Principles of geographical information systems. New York: Oxford University, 1998. 333 p.

CARVALHO, L. M. T. Detecção de modificações na cobertura do solo. In:__ Inventário florestal de Minas Gerais: monitoramento da flora nativa 2005-2007. Lavras: UFLA, 2008. 357 p.

\section{CARVALHO, L. M. T. Mapping and monitoring forest} remanants: a multi-scale analysis of spatio-temporal data. 2001. 140 p. Thesis (Ph. D.) - Wageningen University, Wageningen, 2001.

CASTRO, F. C.; CENTENO, T. M. Segmentação de imagens geradas por perfilamento a laser para delimitação de árvores individuais em uma área de reflorestamento de eucaliptos. In: SIMPÓSIO BRASILEIRO DE SENSORIAMENTO REMOTO, 12., 2005, Goiânia. Anais... Goiânia: SBSR, 2005. CD-ROM.

COELHO, A. H.; VARGAS, R. M. A. Geração de modelos digitais de terreno a partir de dados de laser scanner aerotransportado em área de floresta usando o software livre GRASS. In: SIMPÓSIO BRASILEIRO DE SENSORIAMENTO REMOTO, 13., 2007, Florianópolis, 2007. Anais... Florianópolis: SBSR, 2007. p. 3653-3660.

CROW, P.; BENHAM, S.; DEVEREUX, B. J.; AMABLE, G. $\mathrm{S}$. Woodland vegetation and its implications for archaeological survey using LiDAR. Forestry, Amsterdam, v. 80, n. 3, p. 101-106, 2007.

DISPERATI, A. A.; SANTOS, J. R.; OLIVEIRA FILHO, P. C.; NEEFF, T. Aplicação da técnica "filtragem de locais máximas" em fotografia aérea digital para a contagem de copas em reflorestamento de Pinus elliottii. Scientia Forestalis, Piracicaba, n. 76, p. 45-55, dez. 2007.

HEURICH, M.; THOMA, F. Estimation of forestry stand parameters using laser scanning data intemperature, structurally rich natural European beech (Fagus sylvatica) and Norway spruce (Picea abies) forests. Forestry, Amsterdam, v. 81 , n. 5, p. 645-661, 2008.

IOKI, K.; JUNICHI, I.; SASAKI, T.; MORIMOTO, Y.; KITADA, K. Estimating stand volume in broad-leaved forest using discrete-return LiDAR: plot-based approach. Landscape Ecological Engeneering, London, v. 6, p. 29-36, 2010 .

JENSEN, J. R. Sensoriamento remoto do ambiente: uma perspectiva em recursos terrestres. São José dos Campos: Parêntese, 2009. 598 p.

JUPP, D.; CULVENOR, D.; LOVELL, G.; NEWHAM, G.; STRAHLER, A.; WOODCOCK, C. Estimating forest LAI profiles and structural parameters using a ground-based laser called Echidna. Tree Physiology, Amsterdam, v. 29, p. 171181, 2007.

KANEGAE JUNIOR, H.; SCOLFORO, J. R.; MELLO, J. M.; OLIVEIRA, A. D. Avaliação de interpoladores estatísticos e determinísticos como instrumento de estratificação de povoamentos clonais de Eucalyptus sp. Cerne, Lavras, v. 12, n. 2, p. 123-136, abr./jun. 2006.

KOCH, B.; HEYDER, U.; WELNACKER, H. Detection of individual tree crowns in airbone lidar data. Photogrammetric Engineering \& Remote Sensing, New York, v. 72, n. 4, p. 357-363, Apr. 2006.

LAURI, K.; JUSSI, P.; JUKKA, M.; AKI, S.; MATTI, M.; PETTERI, P.; JYRKI, K. The use of airbourne laser scanning to estimate sawlog volumes. Forestry, Amsterdam, v. 81, n. 4, p. 499-509, 2008.

LEE, A. C.; LUCAS, R. M. A LiDAR-derived canopy density model for tree stem and crown mapping in Australian forests. Remote Sensing of Environment, New York, v. 111, n. 4, p. 493-518, Dec. 2007.

LILLESSAND, T. M.; KIEFER, R. W. Remote sensingand image interpretation. 4. ed. New York: J. Wiley, 2000. 724 p.

MCCOMBS, J. W.; ROBERTS, S. D.; EVANS, D. L. Influence of fusing lidar and multispectral imagery on remotely sensed estimates of stand density and mean tree height in a managed loblolly pine plantation. Forest Science, Oxford, v. 49, n. 3, p. 457-466, 2003.

MACEDO, R. C. Estimativa volumétrica de povoamento clonal de Eucalyptus sp. através de laserscanner aerotransportado. 2009. Dissertação (Mestrado) - Instituto Nacional de Pesquisas Espaciais, São José dos Campos, 2009.

Cerne, Lavras, v. 18, n. 2, p. 175-184, abr./jun. 2012 
MALTAMO, M.; EERIKÄINEN, K.; PITKÄNEN, J.; HYYPPÄ, J.; VEHMAS, M. Estimation of Timber volume and stem density based on scanning laser altimetry and expected tree size distribution functions. Remote Sensing of the environment, New York, v. 90, p. 319-330, 2004.

MIQUELES, M. A.; CAVASSIM JUNIOR, I.; WEIHING, D.; CENTENO, J. Classificação de imagens obtidas do laser scanner baseada em atributos espectrais e espaciais. In: SIMPÓSIO BRASILEIRO DE SENSORIAMENTO REMOTO, 11., 2003, Belo Horizonte. Anais... Belo Horizonte: SBSR, 2003. p. 1883-1890.

MORSDORF, F.; MEIER, E.; KOTZ, B.; ITTEN, K. I.; DOBBERTIN, M.; ALLGOWER, B. LIDAR-based geometric reconstruction of boreal type forest stands at single tree level for forest and wildland fire management. Remote Sensing of Environment, New York, v. 92, p. 353362, 2004.

NAESSET, E.; BJERKNES, K. Estimating tree heights and number of stems in young forest stands using airborne laser scanner data. Remote Sensing of Environment, New York, v. 78, p. 328-340, 2001.

OLIVEIRA, A. C. Geotecnologia na estratificação de povoamentos de Eucalyptus spp. 2006. Dissertação (Mestrado) - Universidade Federal de Lavras, Lavras, 2006.

POPESCU, S. C.; WYNNE, R. H.; NELSON, R. F. Estimating plot-level tree heights with lidar: local filtering with a canopy-height based variable window size. Computers and Electronics in Agriculture, Oxford, v. 37, n. 1/3, p. 71-95, Dec. 2002.

SASAKI, T.; IMANISHI, J.; IOKI, K.; MORIMOTO, Y.; KITADA, K. Estimation of Leaf Area index and canopy openness in broad-leaved forest using airborne laser scanner in comparison with high-resolution near-infrared digital photography. Landscap Ecological Engineering, Chicago, v. 4, p. 47-55, 2008.

SCOLFORO, J. R. S.; MELLO, J. M. Inventário florestal. Lavras: FAEPE, 2006. 561 p.

SOUZA, C. S.; MOREIRA, A. A.; SCHIMITH, R. S.; BRANDÃO, P. C.; SILVA, E. Técnicas de sensoriamento remoto como subsídios aos estudos de florestas implantadas no Brasil: uma revisão bibliográfica. Ciência Florestal, Santa Maria, v. 17, n. 4, p. 409-417, out./dez. 2007.

TIEDE, D.; HOCHLEITNER, G.; BLASCHKE, T. A full GIS-based workflow for tree identification and tree crown delineation using laser scanning. In: 3D city models, road databases, and traffic monitoring: concepts, algorithms, and evaluation. Vienna: IAPRS, 2005.

YU, X.; HYYPPÄ, J.; KAARTINENE, H.; MALTAMO, M. Automatic detection of harvested trees and determination of forest growth using airborne laser scanning. Remote Sensing of the Environment, New York, v. 90, p. 451-462, 2004.

ZANDONÁ, D. F.; LINGNAU, C.; NAKAJIMA, N. Y. Varredura a laser aerotransportado para estimativa de variáveis dendrométricas. Scientia Forestalis, Piracicaba, v. 36, n. 80, p. 295-306, dez. 2008.

ZONETE, M. F. Análise do uso da tecnologia laser aerotransportado para inventários florestais em plantios clonais de Eucalyptus sp no sul da Bahia. 2009. Dissertação (Mestrado) - Escola Superior de Agricultura "Luiz de Queiroz", Piracicaba, 2009.

ZONETE, M. F.; RODRIGUEZ, R. C. E.; PACKALÉN, P. Estimação de parâmetros biométricos de plantios clonais de eucalipto no sul da Bahia: uma aplicação da tecnologia laser aerotransportada. Scientia Forestalis, Piracicaba, v. 38, n. 86, p. 225-235, jun. 2010.

Cerne, Lavras, v. 18, n. 2, p. 175-184, abr./jun. 2012 